\title{
PAIDEIA AND SOCIAL ASCENSION IN ROMAN AFRICA: THE LIFE OF APULEIUS FROM MADAUROS (2ND CENTURY A.D.)
}

\author{
Belchior Monteiro Lima Neto ${ }^{1}$
}

\begin{abstract}
The comeback of biographical studies in the last decades opens new possibilities of research in what concerns Ancient History. That shows how complex the action of individuals in ancient societies was. Within this perspective, our investigation will focus on the life of Apuleius from Madauros, in order to perceive the importance of Greek-Roman paideia as a fundamental element of social insertion for North-African elites in Roman imperial society. In general terms, the biography of Apuleius could be understood as a model case in the heart of local urban aristocracies, offering us an example of the way in which this group, through the instruction in paideia, experienced social ascension and grasp the new possibilities opened by the advent of Roman domination in that region.
\end{abstract}

\section{Keywords}

Roman empire; Proconsular Africa; biography; Apuleius from Madauros; paideia.

\section{Resumo}

Com o retorno dos estudos biográficos, verificado nas últimas décadas, abrem-se novas possibilidades de pesquisa no tocante à Antiguidade, demonstrando-nos a complexidade da ação dos indivíduos nas sociedades antigas. Dentro desta perspectiva, como objeto de investigação, analisaremos a história de vida de Apuleio de Madaura, com o intuito de perceber a importância da paideia greco-romana como elemento fulcral no processo de inserção social das elites norte-africanas na sociedade romana imperial. Em termos gerais, a biografia de Apuleio pode ser compreendida como um caso modelo no seio das aristocracias citadinas locais, oferecendo-nos uma amostra do modo como

\footnotetext{
${ }^{1}$ Assistant Professor - University of Espírito Santo, Vitória, Brazil. E-mail: belchior67@ hotmail.com
} 
este grupo, por meio da instrução na paideia, ascendia socialmente e se apropriava das novas possibilidades abertas pelo advento do domínio romano na região.

Palavras-chave: Império Romano; África Proconsular; biografia; Apuleio de Madaura; paideia.

\section{Introduction}

In the last decades, Historiography has been through a series of comebacks. Researchers have turned their eyes, once again, on Political History, on the happening, and perceived the intrinsic relations between history and narrative. ${ }^{2}$ The comeback of biography as a center of interest for historians is related to a period of uncertainties, of epistemological crisis to which these studies have been confronted from the 1960's. Biography, which comes back to surface now, is no longer concerned about telling the life of men "predestined" to accomplish great historical actions, mainly identified with political and military history. The present possibilities point out an analysis of these personalities' lives, related to the context of their existences. A context that, far from determining human actions and deeds, becomes an element through which individuals build their world, make choices and act in the pursuit of their interests (Loriga, 2011: 211-231). In the words of Chartier (1994: 98): there was an epistemological turn of history towards the individual, and the attention is now focused on "the application of imposed rules rather than on the rules themselves".

From this new perspective on biographical studies, our object of investigation will be the life of Apuleius from Madauros, in order to perceive the importance of Greek-Roman paideia as an element of distinction and prestige, understating its importance as a means of social ascension. We believe paideia to be a set of literary, rhetoric, oratory, political, philosophical, and mythological learnings founded on the principles of classical Greek-Roman culture - it became then an indispensable component for reaching an outstanding position in the imperial society. In general terms, we see the facts that happened during Apuleius' life as a model case in the heart of urban elites of Northern Africa. That provides us with an example of the wat in which local aristocracies of various North-African cities, through the instruction in paideia, made their insertion in the imperial society and grasped new possibilities opened by the advent of Roman domination in that region.

\footnotetext{
2 A detailed problematization about the questions that associate present historical literature with happening, narrative and political history can be seen in authors such as René Rémond (2003), Roger Chartier (1994), Paul Ricoeur (1997), and Michel de Certeau (1982).
} 


\section{Apuleius Madaurensis}

Concerning Apuleius, there are several controversies about his biographical data, as it happens to most authors of Ancient times. What we consider to be the author's biography is therefore a result of a compilation of data extracted from the close analysis of documents, with alternated clues from new information, varying from simple suppositions to strong evidence, with Apuleius himself including many autobiographical elements in his works, mainly in three of them: Apologia, Florida and Metamorphoses. ${ }^{3}$

Apuleius was probably born in the decade of 120, in Northern Africa, and lived under the governments of Hadrian (117-138), Antoninus Pius (138-161) and Marcus Aurelius (161-180). His date of birth can be inferred from some passages of his works. In Florida (XVI, 36-37), Apuleius claims to have been a companion of studies of former consul Emilianus Strabo: we can therefore suppose that both had almost the same age. As though Strabo was 32 when he became a consul, in 156, that leads to the conclusion that both might be born on the third decade of the second century (Harrison, 2000: 3). ${ }^{4}$ This date is corroborated by the fact that in Apologia $(89,5-6)$, Apuleius declares to be slightly younger than his wife, Emilia Prudentila, who is commonly admitted being 40. As though the judgment that inspired the writing of Apologia occurred in $159,{ }^{5}$ this chronology leads to assume that the author was in his thirties by that time.

Everything indicates that Apuleius was born in Madauros, ${ }^{6}$ a Roman colony founded in Numidia by army veterans in the Flavian period (69-96), which

\footnotetext{
${ }^{3}$ In what concerns the works written by Apuleius, there is a large variety of styles: speeches, philosophical texts, poetries, Latin novels, hymns, panegyrics, botanic, zoology, medicine and astrology treaties and others. In short, Apuleius was a versatile author of different literary genres, writing as well in Greek as in Latin. Only 6 works out of his vast production have subsisted to our days: one Latin novel (Metamorphoses), three philosophical treaties (De Platone, De Mundo, and De Deo Socratis), one juridical speech (Apologia), and one laudatory speeches anthology (Florida).

${ }^{4}$ In Florida (XVI, 40), Apuleius refers to Aemilianus Strabo as vir consularis. According to Corpus Inscriptionum Latinarum (VI, 2067; 2086), Strabo was a consul in Rome in the year 156.

5 The date of Apuleius' trial in Sabrata can be determined by crossing data from Apologia $(94,5)$ with three epigraphic inscriptions found in the Lepcis' theater (Inscriptions of Roman Triplitania, 533;534; 535), which prove Lolianus Avitus was the proconsul in 157/158. As Apuleius was judged by Claudius Maximus, who succeeded Avitus in the administration of Africa, we believe the madaurian author to have been judged in the year 159 (Guey, 1951: 308).

${ }^{6}$ Madauros is nowadays the Algerian city of Mdaurush.
} 
can be deduced from a local epigraphic inscription designing it as Colonia Flavia Augusta veteranorum Madaurensium (Inscriptions Latines de l'Algérie, 2152). By the time of Apuleius, Madauros was a city of small size, located 230 kilometers East from Carthage, and 900 meters above the level of the sea, in the Southern versant of the Atlas chain, sharing a frontier with some of the semi-nomad tribes that lived Southern Numidia, mainly the Gaetulis and the Musulamii (Harrison, 2000: 4). ${ }^{7}$ Apuleius himself, in Apologia (24, 1-10), describes his homeland "located in the border of Numidia and Getulia" and himself as being "half-Numidian and half-Gaetuli". To corroborate this last piece of information, one could also mention two stone divisor marks found in the boundaries of the city of Madauros, suggesting that the region was a frontier region between the Madaurenses and the Musulanii (I.L.ALG., 2828; 2829).

Madauros can be considered the place of birth of Apuleius thanks to some quotes made by the author and some supplementary sources. In Apologia (24, 8-9), Apuleius describes his homeland as a Roman colony founded by veterans in Southern Numidia, a location that corresponds to the region in which Colonia Madaurensium was established. In addition to this, as the Metamorphoses have an autobiographical bias, in which the protagonist, a Greek named Lucius, represents a sort of alter ego of Apuleius himself, we might understand the affirmation according to which the character of Lucius was a Madaurensis as an indication that Apuleius, in reality, declares himself as being from the city of Madauros (Metamorphoses, XI, 27).

Besides, this designation is corroborated by the discovery of a statue pedestal with a fragment of a dedicatory from the citizens of Madauros to a platonic philosopher whom the city was proud of. This text says: "the citizens of Madauros have included in public expenses this statue of the platonic philosopher who is a source of honor for them" (I.L.ALG., 2115). ${ }^{8}$ Even though we cannot be sure the statue was attributed to Apuleius, the text mentions a philosopher of the platonic school and as there is no information about another prominent philosopher of that region, everything leads to believe that this statue was built as an homage to Apuleius, known in Ancient times as philosophus platonicus Madaurensis (Gaisser, 2008: 29-36). ${ }^{9}$

\footnotetext{
${ }^{7}$ Many authors, such as Mahjoubi (1985), Raven (1993), and Chausa (1994), highlight the importance of these colonies to reinforce border control and contain possible attacks from nearby semi-nomad tribes.

8 Translation of the latin prepared by the author.

9 Madauros was also designated as Apuleius' hometown by Augustine of Hippo (De civitate Dei, 8, 14; Epistolae, 102, 32), who referred to the author, in early $5^{\text {th }}$ century, as Philosophus platonicus madaurensis.
} 
Apuleius' family, according to some data presented by the author himself, belonged to municipal North-African oligarchy, i.e., to the ordo decuriorum of the city of Madaura. In Apologia (24, 8-9), Apuleius declares that his father reached the highest place in municipal judiciary administration - that is to say, the one of duumvir,$-^{10}$ leaving to his sons a heritage of two million Sestertii, which was enough for them to enjoy an elevated social status. ${ }^{11}$ Through remaining Madaurian epigraphy, we can see that the Apuleii family was one of the most important in the colony. José d'Encarnação (2010: 109-120) suggests that the very fact that they could afford stone carvings in their epitaphs indicates a high social position and the existence of ancestors important enough to be remembered and upraised by the other citizens, as it happened to Apuleius Rogatus, Apuleius Rufus, Apuleia Quarta, and Apuleius Datianus Ponponianus, which were probably individuals with a certain degree of kinship with Apuleius and prominent members of madaurian society (I.L.ALG., 2276; $2277 ; 2278 ; 2279 ; 2236){ }^{12}$

In what concerns Apuleius' paideia, ${ }^{13}$ as evidence indicates, he might have started his education in the city of Madauros, devoting himself to elementary Greek-Roman studies: arithmetic, reading and writing (Harrison, 200: 5). Even if we do not have any consistent information about this early period of Apuleius' life, as a youngster who belonged to the superior classes of roman provincial society, he was likely to pursue his initial education in the literator's school, to where the sons of the members of local urban elites were headed from the age of seven (Marrou, 1956: 265-266).

Between the ages of 11 and 12, we can envisage Apuleius to have been sent, as it was usual to those who could pay for finer studies, to the grammaticus' scho$\mathrm{ol}$, the second level of Roman educational system. In this phase, students learned notions of rhetoric, eloquence, and classic literature, alongside with mythology lessons, knowledges that were fundamental for their future as public

10 The duumviri were the most important magistrates of a roman civitas and were elected every year to be responsible for a citiy's administration (Alföldy, 1996: 177).

${ }^{11}$ In many big or medium cities, like Carthage, in Northern Africa, or Como, in Northern Italy, the minimum income to be eligible to be a decurion was one hundred thousand sestertii, an evidence of how opulent the heritage received by Apuleius was (Alföldy, 1996: 175).

12 The Apuleii family is also attested by an epigraph in Theveste, a numidian city near Madauros, a fact that suggests that the gens Apuleii had a prominent position in that region (I.L.ALG., 3178; 3179; 3601; 3608).

${ }^{13}$ We use the term paideia in the sense of an "education founded on the principles of classic culture in order to instill in man the self-control, the decorum, and the love of beauty" (Silva, 2010: 8). 
men and citizens (Opeku, 1993: 33). In order to do this, Apuleius had to leave Madaura and move to a center of higher projection: Carthage. Such data are presented by Apuleius in Florida (XVIII, 15), when the author declares that his "childhood had occurred amongst you [Carthaginians]; you have been my masters; my philosophical doctrine, even if it ripened in Athens, was born here [in Carthage]". Further, Apuleius (Flor., XVIII, 36) completes: "the reward that I pay you, Carthaginians, everywhere, in exchange for what I learned from you in my childhood, [is to present myself] as a disciple of your city".

After years of study in Carthage, Apuleius pursued his education in a more prestigious and cosmopolitan center: Athens. As usual, among Roman elites, around the age of 15 , the youngsters whose family disposed of enough resources could join the rhetor's school, where they had the opportunity of deepening their knowledges on grammar, rhetoric, dialethic, arithmetic, geometry, music, astronomy, and philosophy (Silva, 2010: 8). It might therefore have been in Athens that Apuleius completes his political-cultural education, as he indicates himself:

The first cup, which we are given by the school masters, delivers us from ignorance; the second one, which comes from the grammarian, provides us with knowledge; the third one, offered by the rhetor, delivers us the weapons of eloquence. Most people are satisfied to drink until this limit. I have sought other cups in Athens: the one of poetry, replete with creative imagination; the one of geometry, with neat transparency; the one of music, full of sweetness; the one of dialethic, quite austere; and, above all, the one of universal philosophy, which abounds in endless nectar (Apul., Flor., XX, 2-4).

Still in Athens, Apuleius was interested in philosophy, especially Plato's one, as we can deduce from the two philosophical treaties he would write later: De Mundo, a synthesis of Aristotelian cosmology; and De Platone, a summary of Plato's life and the teachings. In Athens, moreover, Apuleius was probably interested in questions about the mystery religions, as we can observe in the following passage of his Apologia $(55,8)$ : "In Greece, I took part in the initiations [...] of most mystery cults. I still conserve, with tenderness, some symbols and records of such cults".

After completing his education in Athens, Apuleius is likely to have headed to Rome. ${ }^{14}$ In the Capital of the Empire, the author probably tried a lawyer

${ }^{14}$ Before going on his route to Rome, Apuleius probably travelled through Asia Minor and visited the regions of Samos and Phrygia, as we can assume from some excerpts of Florida (XV) and De Mundo (326-329). 
career, which we can suppose if we match his life and that of the protagonist of Metamorphoses (XI, 26; XI, 30). According to the conjectures of Coarelli (1989), the stay of Apuleius in Rome could have occurred by the end of the decade of 140 and given the madaurian author the possibility of building a network of friendly relations with distinguished members of Roman senatorial elite, a fact corroborated by a passage of Florida (XVII, 4), in which Apuleius states:

[...] even you [Scipio Orfitus, then governor of Proconsular Africa] are the most irrefutable witness that I tried to obtain the recognition and the appreciation of my education and of my culture, as well in our province as in Rome, among your friends, so you have as many reasons to seek my friendship as I have to wish yours.

After his short stay in Rome, Apuleius returned to Northern Africa in the early 150's, establishing himself, as all indicates, in Carthage. In his homeland, the author made himself a name as a public orator and philosopher, holding public conferences in different North-African cities (Harrison, 2000: 5-6). In Apologia $(73,2)$, we have an example of the activity of public orator that the author exerted, by the time he arrived to Oea:

[...] upon the request of some friends, I hold a public conference to the crowd that gathered in the basilica where the meetings took place; and among many applauses, they shouted unanimously [...] that I should become a citizen of Oea.

The stay of Apuleius in Oea began in the year 157, during a travel whose destination was Alexandria, in Egypt. When Apuleius passed through Oea, he fell ill and stopped in the house of some of his friends (Apul., Apol., 72, 1-3). While he was recovering from his journey, Apuleius met his former companion of studies, Pontianus, "whom he had been introduced to in Athens some years earlier by common friends and whom he had kept a close friendship with" (Apul., Apol., 72, 4).

Wishing to find a distinguished husband for his mother, Emilia Pudentilla, who was a widow, Pontianus convinced Apuleius to stay a little longer in Oea, "waiting for the next winter" before pursuing his travel (Apul., Apol., 72, 5). After several attempts by Pontianus to arrange this matrimony, Apuleius gave in and accepted to spouse Pudentilla, putting an end to his itinerant life as a public orator (Apul., Apol., 73, 7-8). The marriage, however, was not well seen by the family of the widow's former husband. Emilia Pudentilla had been married to Sicinius Amicus and, after his death, the alliance between the two families had not been broken, since a contract had been set for a future marriage - sponsalia - uniting the widow and her dead husband's brother, Sicinius Clarus (Apul., Apol., 63, 5). 
By marrying Emilia Pudentilla, Apuleius had draught to himself the opposition of a part of local urban elite. The enemies of the author in Oea were mainly Pudentilla's former brother-in-law, Sicinius Emilianus, and her youngest son, Sicinius Pudentis. They formally accused Apuleius - seen as someone who was interested by Pudentilla's heritage - of using magic to obtain the widow's love and marrying her. That is the reason why he was brought in court as a defendant before the Proconsul of Africa in Sabrata in the year 159.

After pleading his cause and being cleared from the charges of using magic, Apuleius settled in the city of Carthage and became famous in the 160's as a writer, philosopher and orator. The distinction acquired by Apuleius in Carthage is attested by the rising of a statue in his homage. The madaurian author states, in a passage of Florida (XVI, 38): "what can I add to such a compliment, made in public by a consular notable [...] [who] promised me that he would rise a statue and cover its costs".$^{15}$

In Ancient times, statues had a well-known social function and served as a means of commemorating the most prominent members of a community; their aesthetical value as art works was secondary. ${ }^{16}$ They were mnemonical artefacts meant to preserve from oblivion those who should be publicly remembered and praised (Stewart, 2003: 8). According to Apuleius (Apol., 14, 2), "a city officially granted personalities the erection of their effigy as a reward for their services, so that [their memory] could be contemplated". The prestige and the honor associated to statues could thus relate to what Arendt (2001: 14) calls man's search of immortality, the desire to give his works and deeds an eternal permanence.

This statue was dedicated to Apuleius due to the fact that he had "a priestly office, [...] enjoying the highest dignity of Carthage" (Apul., Flor., XVI, 38). Unfortunately, the madaurian author does not offer any supplementary piece of information about the kind of priesthood he exerted in that city. Augustine of Hippo (Epist., 138, 19), centuries later, will refer to Apuleius as a sacerdos provinciae Africae, i.e., as a provincial priest, a magistracy held by rich, influential individuals that represented their fellow citizens before the Empire. It was considered the summit of the political career of the most prominent local decurions (Picard, 1954: 168). ${ }^{17}$

15 The statue dedicated to Apuleius was probably a homage after his election for the position of sacerdos Aesculapii in Carthage (Apul., Flor., XVIII, 38; Rives, 1994: 286).

16 The difference between statues and sculptures is that the first have a clear social function and are meant to convey and enhance the prestige of specific individuals, while the other are mostly associated to an aesthetical, artistic value (Stewart, 2003: 8).

17 An exhaustive list of Proconsular Africa provincial priests, attested by epigraphic sources, can be found in Duncan-Jones (1968). 
The public distinction Apuleius was granted in Carthage can be examined through different laudatory speeches written by him. Such oratory performances praised the honor, dignity and wisdom of the most notable individuals of the city, such as proconsuls and prominent members of local elite, a fact that shows how close the author was with important personalities of roman north-African society, as well as his belonging to Carthaginian aristocracy. Alongside with that, Apuleius seized the opportunity of also confirming his own honor as a famous orator, at the same level, in terms of prestige, as the people to whom he paid homage in his speeches.

For instance, there is an excerpt of the laudatory speech in the honor of proconsul Severianus Honorinus (162/163), in which the madaurian author demonstrates publicly all his erudition as a versatile orator, famous in Carthage. More than paying homage to the provincial governor, he elaborates, indeed, a sort of self-compliment:

I write satires and enigmas, different kinds of stories, speeches appreciated by orators and dialogs that rejoice philosophers. I elaborate all these works and other similar, as well in Greek as in Latin, with the same hope, equal enthusiasm and identical style. I wish I could, excellent proconsul, offer you all these works, one by one, [...] and enjoy your testimony about all my creations. Not that I do not need to be renowned - I have been so for a long time and my fame remains intact and flourishing (Apul., Flor., IX, 28-31).

No information about Apuleius is available in the years after the 160 's. There is a hypothesis concerning this final period of his life: by analyzing the didacticism of works like De Platone and De Mundo, that he considers to be posterior to 170, Harrison (2000: 179-180) states that the madaurian author exerted the teaching of rhetoric and philosophy, directing and orienting several pupils. ${ }^{18}$ In short, Apuleius probably ended his days as a grammaticus or rhetor in Carthage and wrote the two works mentioned above to his students (Harrison, 2000: 179-180).

This possibility is corroborated by other data found in Apuleius' two philosophical works. As well in De Platone (I, II, 219) as in De Mundo (285), the author dedicates his writings to a young man called Faustinus, probably his son with Emilia Pudentilla. Since in Apologia, a speech pronounced in 159, there is not any mention to the name of Faustinus as Apuleius' son, we can assume the

\footnotetext{
18 Against this interpretation proposed by Harrison (2000: 179-180), see Macías Villalobos (2011: 93-95), who states that De Platone and De Mundo were written by Apuleius before the 150's, in Athens, while he was studying in the rhetor's school.
} 
child was born in Carthage, perhaps in early 160's. Considering that the usual age to start philosophical studies in the grammaticus' school was around 11 or 12, we could reasonably think De Platone and De Mundo were published in early 170's and that Apuleius, in accord with his academic activities, dedicated the work to his son, possibly a freshman in the Grammaticus' school.

The last trace of Apuleius' biography is the writing of Metamosphoses. In historical literature, there is a certain obscurity about the precise date of this work. ${ }^{19}$ The authors, however, say unanimously that the Metamorphoses were written near the author's death, between the 170's and the 180's. Some information allow to infer that the Metamorphoses were composed after Apologia and Florida, i.e., after the 160's. This conjecture can be confirmed by the absence of any reference to a Latin novel in the works mentioned above, ${ }^{20} \mathrm{a}$ meaningful absence, since the author gives a catalog of his writings in both works (Apul., Apol., 38, 1-2; Apul., Flor., IX, 27-28; XX 5-6).

Another evidence suggests that the Metamorphoses were written in late 170's. Our attention is drawn to an episode in the story of the character Psyche, in which she is told that it is forbidden to give shelter to fugitive slaves (Apul., Met., VI, 4-5). According to Ulpianus (Digestum, VI, 4; VII, 4; II, 6), this law had been edited in 177, during Marcus Aurelius administration - this fact means that the Metamorphoses were written between the 170's and the 180's (Walsh, 1995: 248-251).

In what concerns the date of Apuleius' death, we know very little about it. Except for the consensus that it occurred in the city of Carthage, many authors do not agree on an unambiguous date. Julia Haig Gaisser (2008: 1-2) places Apuleius' death around the year 170, a date also accepted by José Maria Royo (1998: 15), Santiago Segura Munguía (1980: 16) and Paul Vallette (2002: xii). On the other hand, Stephen Harrison (2010: 10) stipulates a date posterior to 180, joining Maria José Hidalgo de la Vega (1986: 9-10), Walsh (1995: 248-251) and Vincent Hunik (1997: 5). It is therefore prudent to settle a flexible chronology in what concerns the author's death, considering the evidences available on that matter are scarce. In accord with specialized literature, Apuleius passed away between the 170's and the 180's.

\footnotetext{
19 Among the main authors whom we referred to in what concerns the chronology of Apuleius' Metamorphoses, we could mention: Gaisser (2008); Harrison (2000); Hanson (1989); Hidalgo de la Vega (1986); Royo (1998); Bradley (2012); Walsh (1995).

${ }^{20}$ A Latin novel can be conceptualized as a literary genre that gathers, around a central theme, different parallel, crossed plots, and in which fantastic, marvelous elements are often present (Silva, 2001: 27).
} 


\section{Conclusion}

Throughout his life, Apuleius reached great distinction, obtaining public functions and the honor to have statues made in his homage, as a recognition of his work of orator and philosopher. In this context, he must be perceived as a renowned member of roman aristocracy, an individual who earned a position of prestige among his peers thanks to his exceptional erudition. In general terms, Apuleius' paideia should be seen as an extraordinary instrument in the competition for visibility and prestige. It is not by chance that Apuleius, a decurion from a small, remote city in the limits of the Orbis Romanorum, through his cultural education, could experience such a social ascension, putting himself at the same level as consuls and proconsuls, prominent members of the most important roman social order, the senatorial one.

Having started his studies in Madaura, a peripheric city of Numidia, and pursuing them in renowned centers such as Carthage, Athens and Rome, Apuleius followed a path that was usual for the members of urban north-African elites. Similar examples can be seen in the biographies of several local personalities. We could mention Marcus Cornelius Fronto, born in Cirta, and Salvius Julianus, from Hadrumetum, as prominent men from the same region and time as Apuleius who became notorious thanks to their exceptional erudition, reaching positions of prestige in the imperial administration (Keulen, 2014; Raven, 1993: 124-126). The Aemilii family, from Oea, could also be mentioned: their commitment to education, as we can see in the case of Pontianus, who studied philosophy with Apuleius in Athens, allowed them to ascent to the ordo senatorius in early 180's, a fact proven by epigraphic inscriptions that designate Lucius Aemilius and Aemilius Frontianus as proconsul of Asia and sacerdotes domus Augustae Palatinae, respectively (I.R.T., 230; C.I.L., VI, 2010).

Besides being paradigmatic of the social ascension process of north-Africans in the Empire, Apuleius biography can be studied to relativize dichotomic interpretations about Roman-African society, which sometimes value roman influences on that region, sometimes emphasize the importance of native elements in the construction of local history. In this sense, critical studies are fundamental to the secular concept of romanization. ${ }^{21}$ From the 1990's,

${ }^{21}$ The term romanization was at first used to explain the contacts between the Romans and the peoples they conquered, highlighting the acculturation process suffered by autochthonous populations, which took on the aesthetic patterns, the language and the values of their conquerors. It was assumed that there was a cultural disparity between Romans and Provincials, a relation that led researchers to build dichotomies such as "civilized vs primitives". Such a vision ignored the autonomy of historical agents in face of the social, cultural processes in which they took part and put the populations conque- 
a new understanding of the relations between Roman Empire and autochthonous north-African populations has emerged, ${ }^{22}$ giving place to a multifaceted perception of sociocultural transformation. As Revell says (2011: 2): "[...] more than expecting homogeneity, we need to recognize that there was an inherent paradox of similarity and variability as a fundamental component of roman identity".

To corroborate this perspective, Janet Huskinson (2000a, 2000b) points out the existence, between the $1^{\text {st }}$ and the $2^{\text {nd }}$ centuries $\mathrm{AD}$, of a common ground, shared in a large measure by diverse elites that took part in the Orbis Romanorum. ${ }^{23}$ The mastery of Latin, the Roman citizenship, the participation in public offices, worship services and civic festivities; the enjoying of urban benefits in theaters, amphitheaters and baths, as well as the diffusion of an education based on the paideia were common elements that gave meaning to what could be called "Roman". Such a conception would not invalidate, according to Huskinson (2000a: 121), the multifaceted dynamics of provincial societies, once this common ground was adopted, experienced and assimilated in diverse ways in the different regions of the Empire. In short, we could refer to the insight of Mattingly (2011: 236-245) and say that the various ethnicities subordinated to roman domination gave new meanings to the common elements of roman identity, in accord with their own interests and traditions, see themselves as Romans and simultaneously keep their identity bonds to their ancestral culture.

Considering these insights brought by Revell (2011), Huskinson (2000) and Mattingly (2011), we can understand what Apuleius states about his homeland and origins as crucial to seize the meaning of roman identity in Northern Africa:

In what concerns my homeland, you have told, based upon my own writings, that it is located in the boundaries of Numidia ang Getulia. As a matter of fact, I have myself said in a public conference [...] I was

red by the power of Roman Empire in a passive position before what was supposed to be culturally superior. The concept of romanization constituted a process in which the other became civilized by becoming a Roman (Mendes, 2007: 38-39).

${ }^{22}$ In what concerns the new biases on the relation between Romans and provincial populations, see Revell (2011), Hingley (2010), and Mattingly (1996; 2011).

${ }^{23}$ The appropriations of this roman common ground was for sure not limited to local elites. If we take the concept of cultural circularity as proposed by Ginzburg (2006), i.e., forms of cultural interrelation between different social layers, we can see various day-by-day situations in which this "elite culture" could be disseminated and assimilated by the humiliores: for instance, the events that took place in theaters, amphitheaters, basilicas and circus and were open to a public larger than the local ordo decurionum. 
half-Numidian ad half-Gaetuli. I do not see why I should be ashamed of this more than Cyrus, the Elder, ${ }^{24}$ of being a half-breed [...], since there is no reason to take into consideration the place in which one is born, but the education one has. [...] I do not say so because I am ashamed of my homeland - I never would, even if we were King Syphax's citadel. ${ }^{25}$ Once we won him, we became the subjects of King Masinissa, ${ }^{26}$ through a gracious concession of roman people, then after a new foundation, we were turned into a very prosperous colony. In this colony, my father had the high position of duumvir $[\ldots]$ and I have the same position in this beloved city, since I joined its Curia, keeping myself at the level this position demands (Apul., Apol., 24, 1-10).

We can conclude from the passage above that Apuleius saw himself as a hybrid individual, half-Roman, half-Gaetuli/Numidian. The miscegenation inherent to his identity was no obstacle to his position as a roman citizen: one proof is his political participation in the Curia of Madauros, by that time a roman colony, a fact that made of that city a territorial extension of Rome itself. Therefore, Apuleius identified himself as well as an African - this is clear in the moment he affiliates to autochthonous groups and remembers the numidian history of his homeland - as well as a Roman, since he had an education based upon the paideia, an element of distinction and identification of roman elite and an indispensable component in the acquisition of a prominent position in the imperial society. ${ }^{27}$

${ }^{24}$ Cyrus, the greatest of Persian kings in Ancient times, was half-Mede, from his mother Mandane, and half-Persian, from his father Cambyses I (Munguía, 1980: 95).

${ }^{25}$ Syphax was a numidian king who played an important role in the Second Punic War, being defeated by roman troops and transported to Rome for the triumphal procession of Scipio Africanus (Raven, 1993: 45).

${ }^{26}$ Masinissa, rival of Sifax, collaborated with Scipio Africanus in the fight against the Carthaginians. After roman victory in Zama, he received the sovereignty over the lands of Numidia (Munguía, 1980: 96).

27 As Bradley puts it (2012d: 145-146), Madauros, Apuleius' hometown, was a civitas influenced by the Punic and the Old-Libyan cultures. We can read, in the epigraphic inscriptions from Madauros, names L. Julius Zabo, Manilius Aris and Mizguar, son of Baric (I.L.ALG., 2547; 2601; 2624). In the Apuleii family, for example, there is an individual whose name is C. Apuleius Rogatus, which corroborates the possibility of a Roman-Punic ascendance of Apuleius himself (I.L.ALG., 2276; 2277). 


\section{REFERENCES}

Primary printed documentation

AGOSTINHO. A cidade de Deus. Tradução de Oscar Paes Lemes. Rio de Janeiro: Vozes, 2002.

APULEIO. O asno de ouro. Tradução e notas de Francisco Antonio de Campos. Lisboa: Europa-América, 1990.

APULEIO. Sobre o deus de Sócrates. Tradução de Rosângela Maria Souza Silva. São Paulo: USP, Dissertação de Mestrado, 2001.

APULEYO. Apología y Flórida. Introducción, traducciones y notas de Santiago Segura Munguía. Madrid: Gredos, 1980.

APULEYO. Obra filosófica. Introducción, traducciones y notas de Cristóbal Macías Villalobos. Madrid: Gredos, 2011.

AUGUSTINE. The letters of St. Augustine. Translated by J. Sparrow Simpson. New York: The Macmillan Company, 1919.

JUSTINIANO. El digesto de Justiniano. Tomo I, II, III. Traducción de A. D'Ors. Pamplona: Aranzadi, 1972.

\section{Archaeological documentation}

CORPUS INSCRIPTIONUM LATINARUM: vol. VIII/ vol. VI. Berlin: Academy of Sciences and Humanities, 1881.

INSCRIPTIONS OF ROMAN TRIPOLITANIA. Rome: British School at Rome, 1952.

INSCRIPTIONS LATINES DE L'ALGERIE. Paris: Librairie ancienne honoré champion, 1922.

RECHERCHES ARCHEOLOGIQUES EN ALGERIE. Paris: Ernest Leroux Editeur, 1893.

\section{Supporting works}

ALFÖLDY, G. Historia social de Roma. Madri: Alianza Editorial, 1996. 
ARENDT, H. Entre o passado e o futuro. São Paulo: Perspectiva, 2001.

BRADLEY, K. Apuleius and Antonine Rome: historial essays. Toronto: University of Toronto Press, 2012.

BUSTAMANTE, R. M. da C.; DAVIDSON, J.; MENDES, N. M. A experiência imperialista romana: teorias e práticas. Tempo, Niterói, v. 9, n. 18, p. 17-41, 2005.

CERTEAU, M. de. A escrita da história. Rio de Janeiro: Forense Universitária, 1982.

CHARTIER, R. A história hoje: dúvidas, desafios, propostas. Estudos históricos, Rio de Janeiro, v. 7, n. 13, p. 97-113, 1994a.

CHAUSA, A. Modelos de reservas de indígenas en el África romana. Gerión, Madrid, n. 2, p. 95-101, 1994.

COARELLI, F. Apuleio a Ostia? D'Arch, n. 6, p. 27-42, 1989.

D'ENCARNAÇÃO, J. Epigrafia: as pedras que falam. Coimbra: Imprensa da Universidade de Coimbra, 2010.

DUNCAN-JONES, R. P. The chronology of the priesthood of Africa Proconsularis under the principate. EpigStud, n. 5, p. 151-158, 1968.

em 1990).

GAISSER, J. H. The fortunes of Apuleius and the Golden ass. New York: Princeton University Press, 2008.

GUEY, J. Au theater de Leptis Magna. Le proconsulat de Lollianus Avitus et la date de l'A pologie d'A pulée. Revue des Études latines, n. 29, p. 307-317, 1951.

HANSON, J. A. Introduction. In: APULEIUS. Metamorphoses: books I-VI. London: Loeb Classical Library, 1989, p. ix-xiv.

HARRISON, S. J. Apuleius: a latin sophist. New York: Oxford University Press, 2000.

HIDALGO DE LA VEGA, M. J. Sociedad e ideología en el império romano: Apuleyo de Madaura. Salamanca: Ediciones Universidad de Salamanca, 1986.

HUNINK, V. Introduction. In: APULEIUS. Pro se de magia. Amsterdam: Gieben, 1997, p 1-22. 
HUSKINSON, J. Elite culture and the identity of empire. In: (Org.) Experiencing Rome: culture, identity and power in the roman empire. New York: Routledge, 2000a, p. 95-124.

HUSKINSON, J. Looking for culture, identity and power. In: Experiencing Rome: culture, identity and power in the roman empire. New York: Routledge, 2000b, p. 3-28.

KEULEN, W. Fronto and Apuleius: two African careers in the Roman Empire. In: LEE, B. T.; FINKELPEARL, E.; GRAVERINI, L. Apuleius and Africa. New York: Routledge, 2014, p. 129-153.

LORIGA, S. O pequeno $x$ : da biografia à história. Belo Horizonte: Autêntica, 2011.

MACÍAS VILLALOBOS, C. Introducción. In: APULEYO. Obra filosófica. Madrid: Gredos, 2011, p. 5-35.

MAHBOUBI, M. Les élites municipals de la Numidie: deux groupes, étrangers à la cité et vétérans. Aufstieg und Niedergang der romischen welt, Berlin, v. 2, p. 673-681, 1982.

MAHJOUBI, A. O período romano e pós-romano na África do norte. In: MOKHTAR, G. (Coord.). História geral da África. São Paulo: Ática, 1985, p. 473509.

MARROU, H. I. A history of education in antiquity. Madison: The University of Wisconsin Press, 1956.

MATTINGLY, D. J. Imperialism, power and identity. Princeton: Princeton University Press, 2011.

MENDES, N. M. Império e romanização: estratégias, dominação e colapso. Brathair, São Luis, n. 7, p. 25-48, 2007. Disponível em: <http:/ / www.brathair. com>. Acesso em: 15 fev. 2010.

MUNGUÍA, S. Introducción general. In: APULEYO. Apología e Flórica. Madrid: Gredos, 1980, p. 7-49.

OPEKU, F. A commentary with introduction on the Florida of Apuleius. Tese, London: University of London, 1974.

PICARD, G. C. Les religions de l'Afrique antique. Paris: Librarie Plon, 1954.

RAVEN, S. Rome in Africa. London and New York: Routledge, 1993. 
RÉMOND, R. Do político. In: Por uma história política. Rio de Janeiro: FGV, 2003, p. 441-454.

REVELL, L. Roman imperialism and local identities. Cambridge: Cambridge University Press, 2011.

RICOEUR, P. Tempo e narrativa. Campinas: Papirus, 1997.

RIVES, J. B. The priesthood of Apuleius. The American journal of Philology, Baltimore, v. 115, n. 2, p. 273-290, 1994.

ROYO, M. J. Introduccíon. In: APULEYO. El asno de oro. Madrid: Letras Universales, 1998, p. 11-50.

SILVA, G. V. da. A formação dos cidadãos do céu: João Crisóstomo e a christon paideia. Acta Scientiarum, Maringá, v. 32, n. 1, p. 7-17, 2010.

SILVA, G. V. da. Um exemplo de polêmica religiosa no século II d.C.: a oposição Ísis x Atargatis nas Metamorfoses de Apuleio. Revista de História da UFES, Vitória, n. 9, p. 27-39, 2001.

STEWART, P. Statues in roman society. London: Oxford University Press, 2003.

VALLETTE, P. Introduction. In: APULÉE. Apologie et Florides. Paris: Les belles lettres, 2002, p. v-xxxviii.

WALSH, P. G. The roman novel. London: Cambridge University Press, 1995. 